\title{
Pengenalan Teknologi Penyediaan Bibit Berkualitas Multi Entris Untuk Percepatan Perolehan Produksi Tinggi Tanaman Jarak Pagar Dalam Rangka Pengembangan Desa Mandiri Energi Ramah Lingkungan
}

\author{
Bambang Budi Santoso*, I Gst. Md. Arya Parwata, I Nym. Soemeinaboedhy S. \\ Pusat Studi dan Pengembangan Tanaman Sumber Energi \\ Fakultas Pertanian Universitas Mataram, Mataram, INDONESIA
}

\section{Article history}

Received: 25 Februari 2019

Revised: 19 Maret 2019

Accepted: 20 Maret 2019

*Bambang Budi Santoso
Pusat Studi dan
Pengembangan Tanaman
Sumber Energi
Fakultas Pertanian
Universitas Mataram,
Mataram, INDONESIA
*bbjatropha1963@ gmail.com

*Bambang Budi Santoso

Pusat Studi dan

Sumber Energi

Fakultas Pertanian

Mataram, INDONESIA

*bbsjatropha1963@gmail.com

\begin{abstract}
Jatropha plants in the Amor-Amor area, North Lombok Regency, West Nusa Tenggara have long been growing and developing as land boundaries, yards, and village roads, but are not used as alternative energy sources, then they do not provide results or income. This is due to limited ability to apply technology for create more profitable. On the other side, utilization of irrigation facilities that have been provided in the form of bore-wells is very rarely used in connection with expensive operational costs, especially on fuel components. Extension activities and demonstrations in the provision of multi-entry Jatropha seedlings with the aim of increasing the knowledge of farmer group members for better implementation Jatropha cultivation technology. The results show that the counseling and demonstration provided was quite capable of arousing interest and the need for farmers to adopt introduced technology. Members of the Telaga Valley Farmers Group were at the trying stage and if assistance is continued, farmers will reach the adoption phase, therefore it takes a long time for technology transformation to form an Energy Independent Village.
\end{abstract}

Keywords: cultivation, demonstration, counseling, bore-wells

Abtrak: Tanaman jarak pagar di kawasan Amor-Amor, Kabupaten Lombok Utara, Nusa Tenggara Barat sejak dahulu telah tumbuh dan berkembang sebagai pagar pembatas lahan, pekarangan, dan jalan desa, namun tidak dimanfaatkan dengan baik sebagai sumber energi alternatif sehingga tidak memberikan hasil atau pendapatan. Hal tersebut dikarenakan keterbatasan kemampuan dalam menerapkan teknologi yang memberikan hasil yang lebih menguntungkan. Di lain sisi, pemanfaatan fasilitas pengairan yang telah disediakan berupa sumur bor sangat jarang digunakan sehubungan dengan biaya operasional yang mahal terutama pada komponen bahan bakar. Kegiatan penyuluhan dan demontrasi dalam penyediaan bibit jarak pagar berkualitas multi entries, bertujuan untuk meningkatkan pengetahuan anggota kelompok tani sehingga dapat menerapkan teknologi budidaya tanaman jarak pagar akan lebih baik. Hasil kegiatan menunjukkan bahwa penyuluhan dan demontrasi yang diberikan cukup mampu membangkitkan minat dan kebutuhan petani untuk mengadopsi teknologi yang diintroduksi. Anggota Kelompok Tani Lembah Telaga berada pada tahap mencoba dan jika pendampingan diteruskan maka petani akan mencapai fase adopsi, oleh karena itu dibutuhkan waktu yang panjang untuk transformasi teknologi hingga terbentuknya Desa Mandiri Energi.

Kata Kunci: budidaya, demontrasi, penyuluhan, sumur bor 


\section{PENDAHULUAN}

Kawasan Amor-Amor di Desa Gumantar, kecamatan Kayangan, Kabupaten Lombok Utara merupakan daerah pertanian lahan kering dengan 3-4 bulan bulan basah sehingga termasuk kategori iklim kering tipe D. Kondisi tersebut hanya mampu memberikan peluang pada petani untuk menanam lahanya satu kali dalam setahun (setelah akses mendapatkan solar mengalami kesulitan karena harganya yang mahal). Sebagian besar (40 persen) dari daerah tersebut merupakan lahan sawah tadah hujan, tegalan (20 persen), hutan semak belukar (20 persen), dan sisanya perbukitan kebun.

Pemerintah telah memfasilitasi kawasan Amor-Amor 4 sumur bor air tanah dalam untuk memenuhi kebutuhan air bersih dan juga untuk air irigasi persawahan tadah hujan mereka. Sehubungan dengan meningkatnya harga bahan bakar solar dirasakan sangat berat untuk menggunakan sumur bor tersebut sebagai sumber pengairan. Hal tersebut akan menambah in-put (biaya) produksi tanaman pangan maupun hortikultura yang biasa dilakukan. Lebih lanjut diketahui bahwa luas lahan garapan yang dimiliki oleh masing-masing anggota kelompok tani bervariasi antara 0,5 hektar hingga 1,5 hektar, atau rata-rata 0,75 hektar. Lahan tersebut sebagian besar ditanami dengan tanaman palawija seperti jagung, kacang tanah, dan juga kacang hijau pada saat musim penghujan. Lahan mereka dibatasi oleh pagar hidup berupa tanaman jarak pagar. Demikian juga sepanjang jalan desa sebagian besar tanaman yang digunakan sebagai pagar pembatas adalah tanaman jarak pagar.

Para petani di kawasan Amor-Amor telah bergabung dalam beberapa kelompok tani. Salah satu kelompok tani tersebut adalah Kelompok Tani Lembah Telaga yang didirikan pada tahun 2000 oleh masyarakat dusun Amor-Amor, Desa Gumantar, Kecamatan Kayangan, Kabupaten Lombok Utara yang berjarak $60 \mathrm{~km}$ dari kota Mataram. Tujuan didirikan kelompok tani ini adalah untuk menghimpun petani lahan kering dalam usaha budidaya pertanian dalam rangka meningkatkan kesejahteraan hidup.

Kondisi sosial ekonomi Kelompok Tani Lembah Telaga tidak menguntungkan. Mereka menanam tanaman palawija seperti jagung dan/atau kacang tanah hanya pada saat musim penghujan. Pada musim kemarau, para petani tidak memanfaatkan lahannya untuk bertanam dikarenakan kesulitan mendapatkan biaya pengairan walaupun persawahan dan perkebunan di kawasan ini telah dilengkapi dengan fasilitas sumur bor air tanah dalam. Harga bahan bakar solar cukup tinggi. Karena itu, fasilitas mesin sumur bor tersebut selama 10-15 tahun belakangan ini idle. Pada lain sisi, tanaman jarak pagar di kawasan ini telah tumbuh dan berkembang sejak ratusan tahun. Tanaman jarak pagar tersebut hanya sebagai pagar pembatas lahan, pekarangan, dan jalan desa. Tanaman jarak pagar hanya sekedar dijadikan sumber pengobatan tradisional dan bukan sebagai tanaman yang memberikan hasil atau pendapatan. Namun, pada 3-4 tahun belakangan ini yaitu sejak booming pengembangan jarak pagar sebagai sumber alternatif bahan bakar minyak, sebagian kecil masyrakat (tani) telah mengumpulkan biji-biji jarak pagar untuk dijual kepada pedagang pengumpul. Mereka tidak memikirkan upaya memperoleh produksi yang lebih tinggi, seperi melakukan perbaikan budidaya yang memadai. Belum ada petani yang mengusahakan tanaman jarak secara intensif dengan pola tanam yang sesuai, seperti penggunaan varietas unggul, jarak tanam yang yang teratur, pemupukan dengan dosis maupun saat pemberian yang sesuai, pemeliharaan, maupun penggunaaan biji maupun minyak sebagai bahan bakar penganti minyak tanah ataupun gas.

Permasalahan lain yang dihadapi para anggota kelompok petani adalah: 1) kelompok dirasakan tidak berkembang, 2) kelompok menghadapi kesulitan memperoleh pupuk dan bahan tanaman unggul, 3) disamping masalah yang terkait langsung dengan pertanian juga sering mengalami kesulitan 
memperoleh bahan bakar minyak berupa solar untuk mengoperasikan mesin pompa air guna keperluan irigasi pertanaman, dan juga minyak bakar sehingga lebih sering menggunakan kayu bakar, serta (4) tidak mengetahui teknologi peningkatan hasil tanaman jarak pagar sebagai sumber bahan bakar alternatif.

Sarana dan prasarana penunjang untuk melaksanakan kegiatan penyuluhan dan demontrasi terkait penyediaan bibit berkualitas dari tanaman jarak pagar tersedia sangat memadai. Akses jalan menuju desa dan dusun lokasi tempat kegiatan dilaksanakan dalam kondisi cukup baik dan dapat dilalui kendaraan roda dua dan empat. Jarak antar desa juga cukup dekat. Jarak dari kawasan Amor-Amor, Desa Gumantar dengan kampus Universitas Mataram berkisar $70 \mathrm{~km}$. Dengan demikian akses untuk pembinaan sangat terbuka (peta lokasi pada Lampiran 2). Kondisi mesin pompa sumur bor masih baik (dapat diopersikan). Terdapat populasi (pertanaman tanaman jarak pagar) baik sebagai pagar pembatas pekarangan, kebun, dan juga terdapat hamparan pertanaman jarak pagar bahan penelitian para peneliti Fakultas Pertanian Universitas Mataram. Sarana penunjang lainnya yang dianggap utama adalah bahwa, Tim Penyuluh merupakan Kelompok Peneliti pada Pusat Kajian dan Pengembangan Pertanian Energi (Energy Farming Centre) yang telah memiliki materi pengembangan tanaman jarak pagar seperti disajikan dalam Tabel 1 berikut,

Memperhatikan permasalahan yang dihadapi oleh anggota kelopok tani di kawasan AmorAmor, Desa Gumantar, maka beberapa target untuk mengatasi masalah yang dihadapi tersebut adalah 1) Meningkatkan kemampuan anggota Kelompok Tani dalam budidaya tanaman jarak pagar secara intensif dengan menerapkan teknologi penyediaan bibit berkualitas multi entries sesuai dengan SOP yang telah dikembangkan Pusat Pengembangan Pertanian Energi Fakultas Pertanian UNRAM, 2)Meningkatkan kemampuan anggota Kelompok Tani dalam menanam tanaman jarak pagar sebagai bahan pembatas (pagar) atau intensifikasi pagar pembatas sehingga berfungsi ganda, yaitu fungsi pembatas dan sebagai sumber bahan bakar minyak, dan 3) Mempersiapkan anggota Kelompok Tani dalam memanfaatkan tanaman jarak pagar sebagai sumber energy dalam memanfaatkan sumur bor yang telah difasilitasi oleh pemerintah sebagai sumber pengairan areal pertanaman mereka.

Sedangkan manfaat kegiatan pengabdian pada masyarakat ini diharapkan akan mampu 1) Mengoptimalkan pemanfaatan sumberdaya alam dan manusia, serta mendinamisasikan pengembangan wilayah pedesaan yang bernuansa pada peningkatan produktivitas kerja dan pendapatan petani, 2) Percepatan pembentukan Desa Mandiri Energi berbasis jarak pagar, 3) Meningkatkan efisiensi berusahatani tanaman jarak pagar secara intensif berwawasan agribisnis, 4) Meningkatkan nilai tambah tanaman jarak pagar sebagai pagar pembatas melalui intensifikasi pagar, dan 5) Mengentaskan kemiskinan dan menggantikan secara bertahap penggunaan minyak tanah dan/atau solar dengan biji dan/atau minyak jarak sebagai energi baru terbarukan menuju desa mandiri energi.

\section{METODE}

\section{A. Bahan Pengabdian pada Masyarakat}

Teknologi penyediaan bibit berkualitas multi entries merupakan bahan utama dalam kegiatan penyuluhan dan demontrasi ini. Sebagai bahan untuk demontrasi digunakan pula bibit jarak pagar berumur 3 bulan dan entries tanaman jarak pagar berpotensi hasil tinggi, serta beberapa peralatan untuk menyambung (graft). Penyampaian materi melalui tayangan power point dan dilengkapi dengan demontrasi serta praktek menyambung pada anggota kelompok tani. 


\section{B. Bentuk Pemecahan Masalah}

Memperhatikan persoalan dan solusi yang diusulkan melalui pengabdian pada masyarakat, yaitu memberdayakan Anggota Kelompok Tani maka pendekatan yang digunakan adalah pendekatan pemberdayaan, yang pada kesempatan ini melalui kegiatan penyuluhan dan demonstrasi. Kegiatan penyuluhan tersebut dilaksanakan dengan menggunakan pendekatan pendidikan orang dewasa dan pembelajaran aksi (action learning). Pihak-pihak yang terlibat dalam penyuluhan dan demonstrasi ini meliputi 1) Tim Pelaksana yang berasal dari Fakultas Pertanian Unram berperan menyiapkan semua kegiatan dan teknologi yang akan diterapkan, 2) Aparat Desa berperan mendukung pelaksanaan penyuluhan dan bersama pengurus kelompok tani menyiapkan petani (anggotanya) dan lokasi kegiatan maupun demplot, 3) Petugas Penyuluh Pertanian berperan sebagai tenaga pendamping, dan 4) Kelompok Tani Lembah Telaga dan/atau Guna Sejahtera beserta anggota-anggotanya sebagai khalayak sasaran yang akan melaksakan teknologi yang akan diterapkan.

Sejalan dengan strategi pemberdayaan dan di atas, maka kegiatan penyuluhan dan demontrasi pada Anggota Kelompok Tani Lembah Telaga dan/atau Anggota Kelompok Tani Guna Sejahtera telah dilakukan dengan urutan kegiatan sebagai berikut: 1) Penyusunan program/kegiatan pemberdayaan, 2) Sosialisasi program (pertemuan para stakeholder kunci dan petani di dusun Amor-Amor dan dusun Gumantar), 3) Pelatihan pembibitan tanaman jarak pagar dan kemudian pelatihan penyambungan dengan multi (beberapa) entries pada bibit tersebut untuk menghasilkan bibit berkualitas, dan 4) Pendampingan kelompok tani oleh mahasiswa dan tim pengusul.

\section{HASIL DAN PEMBAHASAN}

Memperhatikan proses, partisipasi kelompok, hasil yang dicapai dari kegiatan pengabdian penerapan Ipteks sebagaimana diuraikan di atas, selama berlangsungnya kegiatan ini peserta yang merupakan anggota kelompok tani terlibat secara aktif dan penuh antusiasme. Keinginan tahuan para anggota kelompok tani sangat tinggi yang ditandai dengan banyaknya diajukan pertanyaan dan keinginan langsung dalam mempraktekan penyambungan bibit. Beberapa pertanyaan tersebut antara lain "Jika kami akan meneruskan dan mengembangkan model Desa Mandiri Energi yang seperti pernah diperkenalkan oleh bapak-bapak terdahulu dari Unram, apakah bapak-bapak Tim Penyuluh (Peneliti) bersedia membimbing kami ?", “Apakah selain dimanfaatkan sebagai energi atau minyak kompor sendiri, adakah pihak yang mau membeli biji-biji jarak pagar kami ?”, “Apakah tanaman jarak pagar kami yang sudah ada (tumbuh) di pagaran rumah kami dan yang tadi disambung dapat digunakan bijiny pada kompor biji jarak yang kami punya ?", dan "apa boleh bibit hasil sambung itu tidak disungkup? Susah cari plastic untuk sungkup itu pak".

Proses penyuluhan dan demontrasi Pengenalan Teknologi Penyediaan Bibit Berkualitas Multi Entris Untuk Percepatan Perolehan Produksi Tinggi Tanaman Jarak Pagar dalam Rangka Pengembangan Desa Mandiri Energi Ramah Lingkungan yang dilaksanakan sudah sesuai dengan rencana dalam arti sebagian besar rencana kegiatan yang direncanakan dapat terlaksana dengan baik. Kegiatan telah dilaksanakan dengan menggunakan prinsip-prinsip pemberdayaan sebagaimana yang telah disajikan pada bab metode pelaksanaan. Petani dan anggota kelompok tani telah diikutsertakan dalam proses ini. Mulai dari sosialisasi program sampai dengan demonstrasi teknik penyambungan biit. Kegiatan ini dilaksanakan pada periode yang relatif singkat yaitu September - November 2015. Walaupun demikian, hasil yang dicapai sudah cukup memuaskan karena transfer pengetahuan dan alih 
teknologi yang diharapkan sudah berjalan. Sebagian besar anggota kelompok tani terlihat nyata antusias ingin mempraktekkan dan berkeinginan untuk menerapkan teknologi yang dianjurkan dalam rangka mempersiapkan bahan tanaman. Berikut adalah pembahasan dan hasil evaluasi yang dilakukan terhadap kegiatan-kegiatan yang telah dilaksanakan.

Berdasarkan hasil evaluasi dari kegiatan pelatihan (penyuluhan) tampak peningkatan pengetahuan betapa pentingnya tanaman jarak pagar sebagai sumber bahan bakar rumah tangga, sikap dan keterampilan petani dalam mempraktekkan bagaimana cara menyambung bibit tanaman jarak pagar. Setelah mereka mendapatkan pelatihan (penyuluhan) petani saat ini sudah memahami dan mengetahui manfaat jarak pagar sebagai sumber alternatif bahan bakar mereka. Lebih jauh juga mereka menyatakan sikapnya yang positif, yaitu mereka ingin mempersiapkan bibit tanaman mereka secara mandiri bahkan ingin menjadikan usaha tani penyedia bibit bagi petani lainnya yang memerlukan. Bahkan berkeinginan untuk mempunyai alat pengepres biji jarak pagar agar mereka dapat memanfaatkan minyak biji jarak pagar sebagai bahan bakar minyak untuk keperluan rumah tangganya sendiri. Hal ini sejalan dengan teori adopsi yang dikemukakan oleh Roger dan Shoemaker (1971) bahwa setelah petani tahu dan memahami inovasi, mereka mempertimbangkan untuk mencoba inovasi tersebut.

Dari hasil evaluasi dan pengamatan terhadap proses pelatihan penyambungan bibit multi entris telah terjadi peningkatan pengetahuan, sikap dan keterampilan pada sebagian anggota kelompok tani. Hal ini terungkap dari hasil tanya jawab terdapat beberapa anggota kelompok tani pernah mendengar dan tidak tahu tentang bibit berkualitas tanaman jarak pagar, namun beberapa di antaranya menyatakan sebatas pernah mendengar. Setelah dilakukan penyuluhan dan diberikan demontrasi pembuatan bibit multi entris beberapa orang anggota kelompok tani terlihat jelas telah terjadi peningkatan pengetahuan, sikap dan keterampilan petani. Saat tanya jawab di saat penyuluhan berlangsung, mereka menyatakan sudah mengetahui, faham dan mengerti tentang manfaat tanaman jarak pagar dan manfaat bibit berkualitas. Sikap mereka juga terlihat sangat positif dengan menyatakan bahwa mereka siap untuk mencoba melalui kegiatan kelompok untuk mempersiapkan bahan tanamannya sendiri.

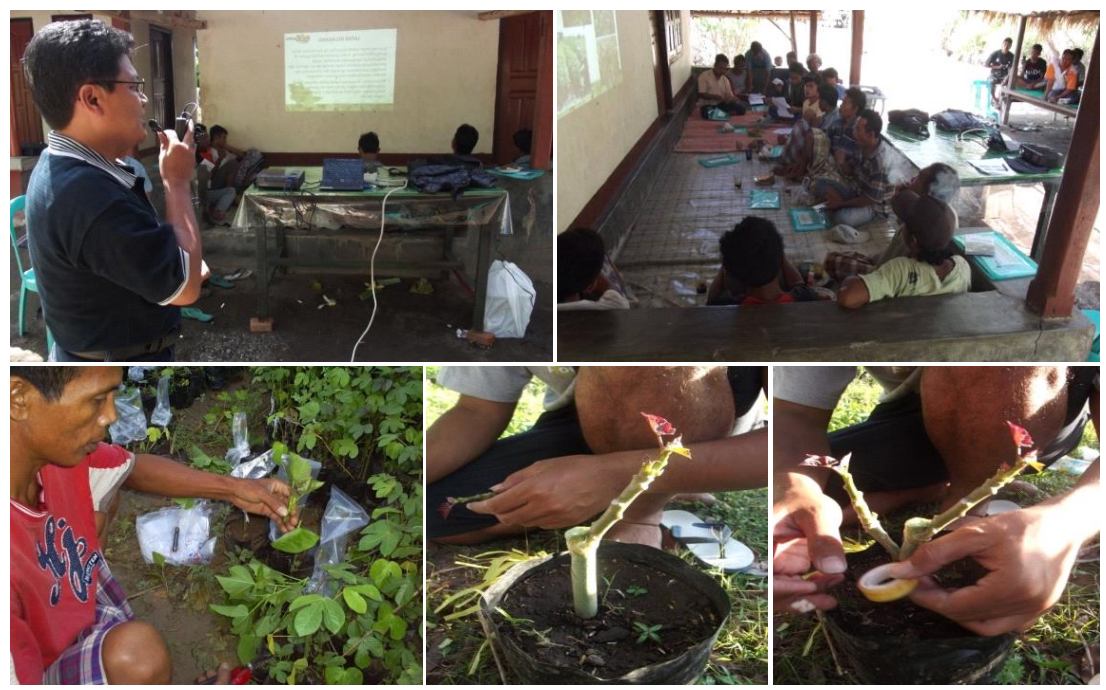

Gambar 1. Kegiatan penyampaian materi penyuluhan dan sosialisasi (atas) dan demontrasi serta pelatihan teknik penyambungan pada bibit tanaman jarak pagar (bawah.

Budidaya tanaman jarak pagar baik sebagai populasi pagar pembatas pekarangan dan jalan desa maunpun sebagai pertanaman intensif dalam tumpangsarinya dengan tanaman pangan dan hortikultura 
merupakan salah satu tujuan yang ingin dicapai dalam penyuluhan dan demontrasi ini. Dari hasil evaluasi dan pengamatan diketahui bahwa telah terjadi perubahan pengetahuan, sikap dan keinginan petani dalam menerapkan budidaya tanaman jarak pagar sebagai sumber bahan bakar mereka.

Hasil pengamatan tim, diketahui bahwa tingkat partisipasi petani dalam penyuluhan maupun demonstrasi pembuatan bibit berkualitas (multi entries) tanaman jarak pagar tampak bahwa mereka penuh antusias bertanya. Beberapa orang anggota kelompok tani menyatakan kekagumannya terhadap penampilan tanaman jarak pagar yang ada di areal penelitian yang dikunjungi. Merekapun menyatakan akan melakukan penanaman tanaman jarak pagar sebagai pagar pembatas pekarangan dan kebun mereka. Dengan demikian dapat dikatakan bahwa proses transfer teknologi yang direncanakan sudah dapat dilakukan dan akan diterapkan kemudian oleh petani. Namun demikian, hal ini masih harus dibuktikan dan dipantau secara terus menerus apakah sesuatu yang telah dikemukakan oleh petani tersebut akan menjadi kenyataan di lapangan. Oleh karena itu, sesungguhnya waktu yang disediakan untuk melakukan penerapan Ipteks ini tidak cukup untuk melaksanakan seluruh rangkaian kegiatan sampai terbentuknya Desa Mandiri Energi berbasis tanaman jarak pagar. Dalam proses menjadikan masyarakat perdesaan dapat mandiri energi dibutuhkan waktu yang cukup panjang. Program ini memerlukan waktu yang cukup panjang. Oleh karena itu, jika program ini diharapkan memberikan hasil maksimal kepada petani atau masyarakat perdesaan, maka program ini perlu dilanjutkan pada tahun berikutnya.

Terdapat beberapa faktor pendorong dan faktor penghambat pelaksanaan penyuluhan dan demontrasi ini. Faktor pendorongnya antara lain adalah tingkat partisipasi yang cukup tinggi dari anggota kelompok tani dan dukungan dari aparat desa. Keberadaan areal pertanaman jarak pagar yang merupakan areal penelitian Tim Penyuluh ini juga memberikan dukungan untuk pelaksanaan kegiatan ini. Sikap kooperatif anggota dan pengurus kelompok tani dalam mengkoordinasikan dan melaksanakan kegiatan penyuluhan dan demontrasi merupakan hal terpenting. Sedangkan faktor penghambatnya adalah, terlambatnya turun dana dan ditandatanganinya kontrak sehingga waktu yang tersedia sangat singkat. Dengan keterlambatan turunnya dana maka terjadi penundaan kegiatan dan sebagaimana diketahui pembibitan tanaman memerlukan waktu 2-3 bulan untuk dapat digunakan sebagai bahan/alat demontrasi dalam pembuatan bibit multi entries berkualitas.

\section{KESIMPULAN DAN SARAN}

\section{A. Kesimpulan}

1. Proses pelaksanaan kegiatan penyuluhan telah dilaksanakan sesuai dengan rencana dan sesuai dengan pendekatan yang telah dirumuskan, walaupun ada beberapa perubahan dan modifikasi, hal tersebut tidak mengurangi efektifitas pelaksanaan kegiatan yang dimaksud.

2. Penyuluhan dan demontrasi yang diberikan cukup mampu membangkitkan minat dan kebutuhan petani untuk mengadopsi teknologi yang diintroduksi.

3. Anggota Kelompok Tani Lembah Telaga berada pada tahap mencoba dan jika pendampingan diteruskan maka petani akan mencapai fase adopsi.

4. Dibutuhkan waktu yang panjang untuk transformasi teknologi hingga terbentuknya Desa Mandiri Energi.

\section{B. Saran}


1. Kegiatan penyuluhan dan demontrasi serta Ipteks untuk pembentukan Desa Mandiri Energi memerlukan periode yang lebih panjang sehingga hasilnya menjadi lebih sempurna.

2. Perlu dukungan dari instansi terkait, agar keberlanjutan program ini dapat dilakukan dan masyarakat dapat merasakan hasilnya secara lebih luas.

\section{Ucapan Terima Kasih}

Tim Peneliti mengucapkan terima kasih atas dukungan dana BOPTN, Kementerian Riset, Teknologi dan Pendidikan Tinggi dengan Surat Perjanjian Pelaksanaan Kegiatan.

No.872/H18.13./PM/2015. Terima kasih disampaikan pula kepada rekan-rekan yang tergabung dalam Energy Crops Centre (Pusat Pengembangan Pertanian Energi) Fakultas Pertanian UNRAM, atas fasilitas dan bahan tanaman yang disediakan.

\section{DAFTAR PUSTAKA}

Bembridge, T. 1991, Practical Guidelines For Agricultural Extension Workers, A Field Manual, Development Bank of Southern Africa, Halfway House.

Freire, P. 1982, Creating Alternative Research Methods, in Creating Knowledge: A Monopoly? Participatory Research in Development, Participatory Research Series No. 1, pp. 29-37.

Hall, C.M. 1992, Women and Empowerment: Strategies for Increasing Autonomy, Hemisphere Publishing Corporation, Washington.

Kindervatter, S. 1979. Non-formal Education as an Empowering Process With Case Studies from Indonesia and Thailand, Center for International Education, University of Massachusetts, Massachusetts.

Kolb, D.A. 1984, Experiential Learning: Experience as A Source of Learning and Development, Prentice Hall, New York.

Lewin, K. 1958. Group Cohesion and Social Change, in Readings in Social Psychology, ed. E.E. Macoby, T.M. Newcomb and E.L. Hartley, Holt, New York

Lord, J. \& Hutchison, P. 1993, The process of Empowerment: Implications for Theory and Practice', Canadian Journal of Community Mental Health, vol. 12, no. 1, pp. 5-22.

Parwata IGMA dan BB. Santoso, 2013. Percepatan perolehan hasil tinggi melalui top working tanaman jarak pagar (Jatropha curcas L.) di lahan kering. Laporan Penelitian Hibah Bersaing. Universitas Mataram, Mataram. 38h.

Putman, A. O. 1991. Empowerment: In Search of a Viable Paradigm, Performance Improvement Quarterly, vol. 4, i. 4, pp. 4-11.

Rappaport, J. 1984, Studies in Empowerment: Introduction to the Issue, Prevention in Human Services, vol. 3, pp. 1-7.

Raven, B. H. \& Rubin, J. Z. 1976, Social Psychology: People in Groups, Wiley, New York.

Riger, S. 1993. What's Wrong With Empowerment, American Journal of Community Psychology, vol. 21, i. 3, pp. 279-292.

Rogers, E. M. 1983. Diffusion of Innovations, Free Press, New York

Santoso, BB., Hariyadi, BS Purwoko. 2007. Tinjauan agro-morfologi perkecambahan biji jarak pagar (Jatropha curcas L.). J. Penelitian Universitas Mataram. Edisi Sain dan Teknologi. Vol.2 No.2. Agustus 2007. 
Santoso, BB., BS Purwoko. 2008a. Pertumbuhan bibit tanaman jarak pagar (jatropha curcas 1.) pada berbagai kedalaman dan posisi tanam benih. Bull. Agron. Vol.XXXVI. No.1.p:70-77.

Santoso, BB., BS Purwoko. 2008b. Teknik pembibitan tanaman jarak pagar (Jatropha curcas L.). Jurnal Ilmiah Budidaya Pertanian - UNRAM, Crop Agro. Vol.1. No.2. p:77-84.

Santoso, B.B. 2009. Pembiakan Vegetatif dalam Hortikultura. Penerbit UNRAM Press. 169h.

Santoso, BB., Parwata, IGMA. 2014. Grafting-teknik meningkatkan produksi tanaman jarak pagar (Jatropha curcas L.). FKIP Unram-Arga Puji Press, Mataram,Lombok. 76h.

Staples, L. H. 1990. Powerful Ideas About Empowerment, Administration in Social Work, vol. 14, no. 2, pp. 29-42.

Suadnya, I.W. Muktasam, A. Saptati, A. Martindah, E. 2008. Pemberdayaan Peternak Sapi Dalam Rangka Peningkatan Produksi Daging : Sebuah Aplikasi Pendekatan Participatory Action Research di Pulau Lombok NTB. Laporan Hasil Penelitian.

Wiesenhutter, J. 2003. Use of Physic Nut (Jatropha curcas L.) to Combat Desertification and Reduce Poverty. Deutsche Gesellschaft fur Technsche Zusammenarbeit (GTZ). Convention Project to Combat Desertification (CCD Project). www.gtz.de/desert [September 2005].

Zimmerman, M. A. 1995. Psychological Empowerment: Issues and Illustration, American Journal of Community Psychology, vol. 23, pp. 581-99. 